\title{
Modeling of a Megaregion's Cultural Code and Methodological Guidelines of Aletology
}

\author{
Olga F. Morozova* \\ Siberian Federal University \\ 79 Svobodny, Krasnoyarsk, 660041, Russia
}

Received 05.05.2017, received in revised form 05.11.2017, accepted 13.11.2017

\begin{abstract}
The article "Modeling of a megaregion's cultural code and methodological guidelines of aletology" is focused on providing the reasons for the necessity to develop scientifically based models of a megaregion's cultural code. The goal is to choose a method of modeling of cultural code of a megaregion as a sociocultural integrity. The central principle is that of cultural centrism integrated with the requirements of the systemic, structural-and-functional approaches and cross-cultural analysis. Theoretical results of cultural studies, philosophy, and psychology are subject to comparison in synchronic and diachronic aspects. The research is based on thew practice of the semiotic approach of the Russian scientific school. The authors have noticed a heuristic significance of the aletology methodology in solving cognitive tasks determined by the practice of a region's sociocultural transformation. The article may be a subject of interest for the specialists in the field of sociology of management and practitioners involved in a megaregion's image formation, finding the ways of its social and cultural unity. Having analyzed the conceptual terms describing the process of a megaregion's cultural code formation, methodology of the research, and the semantic content of cultural code, the author comes to the conclusion that a region's historically evolving ontological unity is not a sufficient ground for functioning of cultural code as the ideological and theoretical basis of unity of a megaregion's segments in today's dynamic conditions. The model-based approach using the aletology principles is preferable for a task-oriented transformation of a megaregion's spiritual space.
\end{abstract}

Keywords: cultural code, megaregion, aletology, methodological guidelines.

DOI: 10.17516/1997-1370-0170.

Research area: culturology.

The research of the "cultural code" phenomenon has become a response to the cognitive challenge of modern times. This challenge is due to, firstly, the role of cultural code in the conditions of the increasing dynamism of socio-cultural processes when the problems of continuity in the process of culture development move into the category of practically important issues. Secondly, globalization, active intercultural polylogues, transformation of cultural boundaries and cultural environments cause a risk of losing ideological and conceptual core of a certain national society. Thirdly, the cultural code formation is conjugated with the processes of purposeful influence on the processes of the regions' national identification,

(C) Siberian Federal University. All rights reserved

* Corresponding author E-mail address: ofmorozova@mail.ru 
self-identity and image development, historical mission implementation.

The severity of the problem is evidenced by the RF President Vladimir Putin's policymaking speeches. They were responded to by the Russian social science of the beginning of the $21^{\text {st }}$ century. As it might be expected, this opened a broad subject-focused field for representatives of various social sciences.

The starting points for our reasoning were the following ones: today there is a need to intensify cultural determinants of the social systems management development (Morozova, 2011). Hence, the importance of cultural code for preservation of stability and territorial integrity of the locus has enhanced. Given that the need in practical use of cultural code is actualized at a purposeful formation of the world of meanings, transition to a conscious use of socially significant forms of human ties with the value universe of culture and that interpretation of the text of culture vary depending on the code used, we consider it to be important to emphasize that the research of cultural code will favour penetration into a new, deep, semantic level of a purposeful formation of the culture of social locus. At that we find out that "we face some paradox: on the one hand, we are impetuously entering the information age, but, on the other hand, the world faces a clear shortage of concepts that are more or less consistent, explaining the strategy and providing the vision" (Sibir': imidzh regiona, 2012: 20-21). This paradox turns into a problematic situation that has arisen particularly at determining the ways of development, tasks and prospects, as well as the image of such a megaregion as Siberia (Sibir': imidzh regiona, 2012: 2021). Analyzing the prospects of Siberia as a megaregion, V.A. Tolokonskii expresses quite a fruitful idea that it is a coherent systematic approach that is vital for a strategic definition of a megaregion, which, in its turn, will improve the quality of planning, form a positive image of a megaregion and its member regions, one of the main challenges for the expert community being the task to find "a model, a pattern according to which Siberia may develop as a megaregion, or create its own unique path of development" (Sibir': imidzh regiona, 2012: 16-17). Thus, to create such a model it is vital to analyze climatic, historic, socio-historic conditions, traditions, national relations, all of which, in our opinion, fit in the broad concept of "culture" and "cultural code" as its base. Cultural code proper is perceived as a model containing principles and rules of formation of each generation's view on the picture of the world. As a meta-level cultural code is regarded as both a part of an element of culture representation and a subsystem of the spiritual world, consisting of some elements.

A large literature makes it possible to trace one thing. It refers to the mosaic of socioeconomic life, the need for the Siberian megapolis unity. Yet, the system-forming element that will make it possible to discover the basis of regional unity has not been found. Arguing about the importance of the image of "Siberia" megapolis, V.I. Suprun (Sibir’: imidzh regiona, 2012: 24-58) points out historical, geographical, industrial, etc. images but leaves a cultural component far behind. We must not forget that the cultural layer of Siberia is quite large and the ways of its development are unexplored, which leads to the spontaneity of cultural work processes. Perhaps, this very aspect should become a public order to Siberian science. To complete this "public order" it is recommended to establish analytical centres the role of which is still under-valued, and these are "strengthening of the regional approach, analysis of interregional policy and forecasting of socio-economic situation development that should be peculiar features of these centres in our region" (Sibir': imidzh regiona, 2012: 21). 
Cultural code is a phenomenon that focuses cultural characteristic features that pass from generation to generation. It is information that makes it possible to identify certain culture. The unity of semantic diversity is the content of cultural code. Cultural code may fail to be defined in logical terms; it is hidden from understanding but constantly finds its expression in life activities. Cultural code functions on two levels common and rational ones, common everyday life often hiding the completeness of meaning. It is not coincidentally that not only cultural studies but also psychology, sociology, and philosophy reflect over the nature and manifestations of cultural code. It is the latter circumstance that determined the reference to aletology which tells about the Truth without opposing various forms of knowledge but recognizing that isolation of human knowledge is always relative and "absolutely reliable knowledge is impossible without understanding its links with other spheres of human knowledge" (Koptseva, 2002: 264).

Application of methodological principles of aletology, which favours climbing to a "higher and at the same time more concrete meaningful level" (Koptseva, 2002: 263) in the course of the cultural code research, leads to the concept of "integrity". Knowledge of the "cultural code" phenomenon as any other knowledge "will be true if and only if it belongs to a holistic system of knowledge, if it is a certain element of a single integrated system and at the same time is an integrated system of content, form, and ways of achievement" (Koptseva, 2002: 264).

Cultural code is based on some synthesizing idea that heuristically, holistically reflects the ontologically existing, evolving, predictable. We agree with the opinion that "based on process-like character and real diversity of true knowledge, true states of human existence, religious experience of absoluteness in its different forms (existential, cognitive, teleological, axiological, etc.), the concept of "integrity" is a result of synthesis of many forms of truth" (Koptseva, 2002: 265). In this case, "linked with the concept of "truth", the concept of "integrity" introduces the characteristics of a goal to the concept of "truth" without obscuring processuality, formation, movement of truth as a path" (Koptseva, 2002: 265-266).

Therefore, modeling of cultural code is based on the principle of integrity leading to the statement that "everything that exists can be a model for all that exists" (Koptseva, 2002: 266).

Culture is the "second nature" and there is always a subject's goal in it. Thus, it can be argued that cultural code is formed purposefully. A subject of socio-cultural management creates an image, understanding: "the standard character of a model is that it models not an infinite number of manifestations of this or that thing but what is the most important and valuable in it for the subject of modeling, what represents a real problem of his/her own existence at the moment" (Koptseva, 2002: 267). Therefore, cultural code constantly bears the impress of the subject of social and cultural management (and this is getting more significant $s)$. In this case the model of cultural code "is always interpretation, in which its author is present inside, the author being the subject of modeling-interpretation and this model being its self-expression" (Koptseva, 2002: 268).

The complexity of designing a model of the Siberian megapolis's cultural code lies in the fact that this megapolis, despite the ontological prerequisites, is relatively young and the objective of its formation and the formation of its image was set not so long ago. It is true to argue that Siberia exists as a social and cultural locus. It is also worth while stating the fact that the dynamic development of Siberia led to the tangle of the immigrants' cultures, the cultures of relatively closed numerous indigenous peoples. 
A kind of hierarchy of cultural codes can be currently revealed. "I am a Siberian", "Siberian character", "Siberia is a spacious, mighty, free land" are the phrases that are far from being meaningless. According to V.E. Vaganov, "It is necessary to rely on peculiar features of Siberian character in working out the conception of the image (of Siberian megapolis - O.M.), the features being an ability to overcome considerable difficulties, non-conflict character, aspiration for collaboration, creative approach to life, love of freedom, and genius of thought, etc." (Sibir': imidzh regiona, 2012: 171). Yet, at the same time an Evenk, Khakas, Buryat and Russian recognize themselves not only as Siberians. A surge of national consciousness in the perestroika and postperestroika periods reversed the elements of the hierarchy of belonging to the culture of locus. Upon closer reflection Siberians' mental structures turn out to be very heterogeneous. Serious scientific researches are needed to determine the roots of the cultural code of Siberia and the Siberians.

Difficulty in understanding of cultural code stems from the fact that since socio-cultural locus and homo kulturalis are a single whole and cannot be absolutely opposed to each other the model of cultural code is both creation and image of the object of modeling and thus the image of one who creates it (Koptseva, 2002). A subject, creating the model of cultural code, lays the ground not only for the present but for the future in it; "future is always born in the model even if the purpose of the model was in understanding or estimation, as understanding and estimation are necessary in order to do something in the model-based future" (Koptseva, 2002: 269). The purpose of cultural code is not just to portray "the future in terms of the present but also to fully transform the vision of those who create and use the models. These are action models which are created under the influence of the epoch and its images" (Koptseva, 2002: 269).
The model of cultural code is closely linked with the model of image creation, the image being, according to E.A. Vaganov, a depth-thing, closely connected with a megaregion's historic fate and focused on the future, whereas the science needs to consider "all possible variants of modern situation development" (Vaganov, 2012: 170-178).

The process of modeling is multivariate. Several types of models can be distinguished, and it seems appropriate to associate modeling of cultural code with the type of models which provide overrunning "beyond the boundaries of the modeling proper to metaphysical ... grounds" (Sibir': imidzh regiona, 2012: 242) of a source of modeling. Thus, there arises the problem of using former conventional terminology. It is appropriate, in our opinion, to accede to the opinion of the productivity of the "belief" term (Sibir': imidzh regiona, 2012: 242). "The belief that perceptions do not deceive us, i.e. sensitive authenticity of feelings and the perception events and things external to the subject" are a primary form of belief (Sibir': imidzh regiona, 2012: 242). Indeed, the statements "I am a Siberian" or "he is a Siberian" do not only represent the individual's confidence in particularities of images, thoughts, feelings, life in general. Evaluation the other people make, perception of special territory are taken into account while planning socioeconomic development at various levels. "The second form of belief is trust in an ideal image of reality, without which implementation of will as well as any action or knowledge are impossible" (Koptseva, 2002: 272).

Is there a conscious aspiration "of an individual or society for the integrity modeled and implemented while modeling when a certain image of the absolute is necessarily included in this model"? (Koptseva, 2002: 272-273). It is likely to exist. In his article "Sibir'kak neraspoznannyi region" ("Siberia as an Unrecognized Region") 
V.S. Efimov was even more specific: "We come close to the issue of necessity to create a Siberian strategy or even own Siberian ideology" (Sibir': imidzh regiona, 2012: 207).

Despite the diversity of the pictures of the world in Siberian peoples' mental structures, we can state that in the Siberians' views the world has never been stiff or lifeless, or disjunct. It is bound, integrated. This general picture of the world has always based on a conceivable unity which is akin to certain absolute, the image of which "is both an ideal of this integrity and a universal field, the action of its modeling taking place inside of it" (Koptseva, 2002: 273). Yet, just as "the ontological meaning of the absolute is in recognition of a single entity of all things, world events and a man that enabled to constantly exceed the boundaries of a given state of existence when the bases for this state of existence have already disappeared" (Koptseva, 2002: 273), the ontological meaning of the cultural code of Siberia is preserved as a key ideological and conceptual core, a center of meaning generation and meaning interpretation, determining the synthesis of economic, social, artistic images that focus on integrity and unity.

All Siberia is a megaregion in which the cultural space is constantly transformed. This transformation is a two-vector one: firstly, the cultural space is developed broad-wise and, secondly, multilayer processes of interpenetration of cultural meanings of the neighbouring regions, synthesis of cultures, blurring of intercultural boundaries are in progress. In this regard V.P. Kozlovskii is right. He defines the cultural meaning as "a cultural form that is developed by historical practice and experience, through which a certain community of people, creating their way of being, lifestyle and culture, learns and understands the surrounding world as a natural reality" (Kozlovskii, 1989: 34).
Besides, the meanings "manifest themselves the way new natural areas and social realities, extending the boundaries of the world, are developed" (Sergeev, 2009: 71).

Cultural meanings cannot be cognized except through "growing accustomed" to them, "penetration into the fabric... of the cultural world" where these meanings exist (Sergeev, 2009: 72). This approach implies new sounding of the methodological guidelines of aletology since, firstly, accumulation of "this worldliness" of phenomena and world events are inseparable with a breakthrough in the "other-worldliness", transcendence, eternity, absoluteness of culture and, moreover, they reflect the attitude to the world, reflection. Secondly, the ontological feature of meaning is its "marginality": "consciousness and existence, ideal and real, values of life and existential possibilities of their realization converge in it" (Vasiliuk, 1984: 129). What is crucial here is that a person "deals not with the natural realities as such but with the cultural meanings representing them" (Pelipenko, Iakovenko, 1988: 11).

Thus, cultural code contains and conveys information, crystallizing it in the system of meanings. This leads to a fair question whether cultural code of the "Siberia" megaregion can be traced as there are many cultures peculiar for the people in Siberia and each culture has its "natural and universal meaning. They are "naturally existing forms of free being", "measure of humaneness", "the border of meaningfulness of the world" in this field. Their relation with the processes of human life is the base, prerequisite of a cultural process" (Sergeev, 2009: 72-73).

The history of the Siberian megapolis formation gives an answer to this question. Despite the variety of time zones distinguished nowadays, the peoples of Siberia co-existed in a specific spatial-temporal field. Siberian chronotopos captures the image of some common 
House where constant changes take place; finite certain things and their states disappear in the infinity, whereas the house still exists like a rainbow; "the unity of the regions of Siberia was in the society's consciousness in the early $20^{\text {th }}$ century already" (Sibir': imidzh regiona, 2012: 16). Such an image is slightly distorted by migration processes causing danger for the destruction of cultural code, evolving for centuries. Representatives of synergy proved that a structurally stable system is ruining the innovation elements as alien ones inside itself. When activated at bifurcation points, the elements of other cultures can destroy the system and lead to a chaos in its development. Chaotic elements in Siberia do not cause total destabilization; it is the mechanism of constructive socio-cultural regulation that starts. We should not forget that the Russian-speaking population of Siberia was formed from the people who deliberately sought freedom, were even adventurous, enthusiastic and determined to learn new things. They were a special kind of super activists. Thanks to them the culture of Siberia became sensitive to bifurcation transitions when the existing cultural mechanisms of determination explode and bring to life the discord "which destroys embeddedness and violates the laws of succession providing the logic of non-linear transition to a new order" (Gorin, 2003: 143). Therefore, hard determining ties were periodically destroyed in Siberia and multi-vector multi-alternative scenarios of culture development emerged in their place.

The tendency of ethnic self-consciousness revival, which was not sensible yet, revealed itself in the post-Soviet period. In general, ethnicity is very elusive, regarding its functionality, and ethno-differentiable signs are quite mobile. The only undisputed factor is geographical location. As a rule, an ethnic group has an idea of "their land" which their ancestors lived on. Revival of ethnic culture has two vectors: on the one hand, return to the ethnic community's value concepts and indigenous cultural traditions can be evaluated positively and a region's cultural policy must fully favour this process. But, on the other hand, a sort of partitions, hindering cultural integration and contributing to negative manifestations of ethnocentrism, are formed in the semantic space of culture. Revival of ideas about primordial space entails the desire to redistribute the territories; new outbreaks of conflicts are also related to temporal orientation of an isolating ethnic group. Archaization of socio-cultural practices is quite possible here. This deepens a social division. This fact further intensifies the research of the Siberian megaregion's common cultural code formation mechanisms.

A megaregion's formation was favoured by a polylogue character as an important feature of cultural meaning. Movement to the East and to the North was not perceived as foreign territories colonization, forcible propagation of their cultural values. It was development, infusion, willingness to cooperate. Processuality of changing forms of meaning formation included appeal to the previously existing codes and their continuous comparison with the codes of "counter" cultures. "Meeting" cultures get a possibility of summation of a complex set of meanings. A.D. Karnyshev (Karnyshev, 1997: 12-13), a researcher of sociocultural processes in Buryatia, notes that in this case ethnic groups get a number of advantages. The interaction processes make it possible for each ethnic group to see themselves "from outside", contrasting and comparing their characteristic features, becoming aware of their features. Interethnic polylogues enrich the semantic universe, revealing the new, introducing innovative elements into the world. Meetings at the "border of cultures" are a powerful impulse of sociocultural dynamics. Siberian culture is polystructural and this minimizes the negative effects of "closed" cultures. Geographical remoteness of 
some Siberian ethnic groups' life contributes to perceptual grasp of their locus as an isolated one from the outside and unalike world, their island in the vast sea. A representative of another ethnic group is not a "strange man". Yet, the severity of climate gave rise to another term, the term being not "strange" but "the other", as well as multiple identities and a sense of community. And the other is met not with hostility but rather with curiosity, bordering with the willingness to learn something useful from him / her. All the mentioned above undoubtedly depends not only on the ethnic groups' will but also on cultural policy. For a megalopolis in the process of its formation it is very important to overcome egocentrism peculiar to each people who live in relative isolation. Recognition of its uniqueness gives way to recognition of other cultures' equality and equivalence.

But the most important thing is that for understanding the cultural code of a megapolis it is necessary to take into account that "the meanings forming the consciousness of one person, or one culture is no different from the meanings determining the consciousness of another person or another culture" (Sergeev, 2009: 75). The Siberians' ontological unity is a fact, and this could not but impose a mark on deep bases of culture and mentality: "When viewed from a broader perspective, human nature and manners show monotony and phenomena constancy", wrote E.B. Tylor (Tylor, 1989: 21). D.V. Sergeev puts forward a thesis "about the presence of the same set of meanings in cultures, the meanings being nearly the same deep inside. This can be explained by cultures' typological similarity, derived from a personality's generic properties and expressed in the form of vital values in universal oppositions, cultural universals, etc." (Sergeev, 2009: 751). The researcher's conclusion is clear: "Cultural differences are determined by different forms in which the same meanings in cultures are expressed" (Sergeev, 2009: 75). It is believed that the hallmark of civilization is not the meaning, but a way of positing the meaning.

A number of semantic systems have always coexisted in parallel In Siberia. And permanent contacts caused mutual benefits to both indigenous peoples and displaced ones. Acculturation was relatively conflict-free, notwithstanding its remoteness from the center, which could impose a strategy of cultural pressure or even parasitism under certain conditions. And there was a gradual synthesis of semantic fields into an integral whole united by a common chronotopos. Assimilation of a semantic field of Russian culture took place in all the forms of manifestation of meaning: mythology, religion, ritual, and symbolism. This is favoured by the ideas of time and space. Spatial meanings can be similar even when architectural structures are different, no matter they are three-storeyed houses or Mongolian yurts (Sergeev, 2009: 75).

A region's cultural code formation undergoes significant transformations particularly during the periods of active social movements when the social time is accelerated. Political reforms gave rise to fluctuations in all local cultural associations. Whereas during "quiet" periods the local level supports and integrates the society, during turbulent transformations sociocultural system loses its integrity. "Fragments" of different social structures face each other in the society: some of them can rapidly restore their own ideas about integrity at certain moments and start the process of archaization while the others are embedded in new structures, thus changing beyond recognition" (Gorin, 2003: 148-149).

Purposeful, thoughtful formation of new cultural meanings, development of the "cultural code" category on the basis of wide empirical material and heuristically productive methodological basis are obstacles to a negative impact of spontaneous forces destructing the socio-cultural unity. Synthesis of the cultural code characteristics is possible only in a holistic, open system of knowledge. 


\section{References}

Gorin, D.G. (2003). Prostranstvo i vremia v dinamike Rossiiskoi tsivilizatsii [Space and Time in the Dynamics of Russian Civilization]. Moscow, Editorial URSS, $280 \mathrm{p}$.

Karnyshev, A.D. (1997). Mezhetnicheskoe vzaimodeistvie v Buriatii: Sotsial'naia psikhologiia, istoriia, politika [Interethnic Interaction in Buryatia: Social Psychology, History, Politics]. Ulan-Ude, Izd-vo BGU, 184 p.

Koptseva, N.P. (2002). Vvedenie v aletologiiu [Introduction to Aletology]. Krasnoyarsk, Krasnoyarsk State University, 342 p.

Kozlovskii, V.P. (1989). Kul'turnye smysly: Genezis i funktsii [Cultural Meanings: Genesis and Functions]. Kiev, Nauk. dumka, 128 p.

Morozova, O.F. (2011). Kul'tura - smyslovaia determinanta sotsial'nogo upravleniia [Culture as a Semantic Determinant of Social Control]. Moscow, ID “ATiSO”, 220 p.

Pelipenko, A.A., Iakovenko, I.G. (1988). Kul'tura kak sistema [Culture as a System]. Moscow, Iazyki russkoi kul'tury, $376 \mathrm{p}$.

Sergeev, D.V. (2009). Ontologiia kul'turnogo smysla [Ontology of Cultural Meaning]. Novosibirsk, Nauka, $167 \mathrm{p}$.

Sibir': imidzh megaregiona [Siberia: Image of a Megaregion] (2012). Novosibirsk, FSPI “Trendy”, $364 \mathrm{p}$.

Tylor, E.B. (1989). Pervobytnaia kul'tura [Primitive Culture]. Moscow, Politizdat, 573 p.

Vaganov, E.A. (2012). Imidzh kak faktor razvitiia nauki i obrazovaniia [Image as a Factor of Science and Education Development]. In Sibir': imidzh regiona [Siberia: Image of a Megaregion]. Novosibirsk, 170-178.

Vasiliuk, F.E. (1984). Psikhologiia perezhivaniia [Psychology of Emotional Experience]. Moscow, Izd-vo MGU, $200 \mathrm{p}$.

\section{Моделирование культурного кода мегарегиона и методологические установки алетологии}

О.Ф. Морозова

Сибирский федеральный университет Россия, 660041, Красноярск, пр. Свободный, 79

\footnotetext{
В статье подтверждается необходимость построения научно обоснованной модели культурного кода мегарегиона. Целью является выбор способа моделирования культурного кода мегарегиона как социокультурной целостности. В качестве центрального принципа предлагается принции культуроиентризма в единстве с требованиями системного, структурно-функционального подходов, кросскультурного анализа. Сопоставляются результаты теоретических разработок культурологии, философии, психологии в синхронном и диахронном аспектах. Используется опыт семиотического подхода отечественной научной школы. Обнаруживается эвристическая значимость методологии алетологии при решении когнитивных задач, продиктованных практикой социокультурных преобразований региона. Материалы статьи могут заинтересовать представителей социологии управления, практиков, занимающихся формированием имиджа мегарегиона, поиском путей его сочиокультурного единения. Проанализи-
} 
ровав понятийный аппарат, описывающий процесс формирования культурного кода мегарегиона, методологию исследования смыслового содержания культурного кода, автор приходит к выводу о том, что наличие исторически складывающегося онтологического единства региона не является достаточным основанием для функиионирования культурного кода как идейнотеоретического основания единения сегментов мегарегиона в современных динамичных условиях, желательно использование модельного подхода с использованием приниипов алетологии при целенаправленном преобразовании духовного пространства мегарегиона.

Ключевые слова: культурный код, мегарегион, алетология, методология.

Научная специальность: 24.00.00 - культурология. 